\title{
Colonisation and modification of soft substratum habitats by the invasive macroalga Sargassum muticum
}

\author{
James A. Strong ${ }^{1,2, *}$, Matthew J. Dring ${ }^{1}$, Christine A. Maggs ${ }^{1}$ \\ ${ }^{1}$ School of Biological Sciences, Queen's University, Belfast BT9 7BL, UK \\ ${ }^{2}$ Present address: Aquatic Sciences, Queen's University, Newforge Lane, Belfast BT9 5PX, UK
}

\begin{abstract}
Sargassum muticum is an invasive brown macroalga that originates from Japan. In the introduced range, thalli can grow in soft substratum habitats attached to embedded rock fragments and shells. Within Strangford Lough, Northern Ireland, S. muticum has rapidly colonised large areas of soft substrata, where dispersal by peripatetic or 'stone-walking' plants is very effective. Sediment cores were collected under and outside canopies of S. muticum in Strangford Lough (S. muticum first recorded there in 1995) and Langstone Harbour, English Channel (S. muticum first found there in 1974) to investigate modification of the infaunal assemblages. At both study sites, community analyses highlighted significant differences between the assemblages under the canopies and those in adjacent unvegetated areas. In Strangford Lough, the invertebrate community under the canopy contained a higher abundance of smaller, opportunistic, $r$-selected species than outside the canopy. By contrast, the communities under and outside the canopy at Langstone Harbour were similar in species composition, diversity and dominance, but overall faunal abundance was greater under the canopy. Sediment characteristics were not affected by $S$. muticum canopies, but the infaunal changes may be related to environmental modification; shading, flow suppression and temperature stratification were also investigated. The differences between these 2 sites indicate that localised conditions and/or the duration of colonisation of $S$. muticum are important in determining the nature of habitat modification.
\end{abstract}

KEY WORDS: Ecological impacts · Infauna · Introduced species · Langstone Harbour · Sargassum muticum $\cdot$ Strangford Lough

\section{INTRODUCTION}

The number of species anthropogenically introduced outside their natural ranges is rapidly increasing (Levin et al. 2002). Although only a very small fraction of transported and introduced species becomes invasive, the ability of these species to restructure and, hence, radically change the functioning of a recipient habitat is great (Crooks 2002). Such is the volume of invasions that this issue is often considered the most severe environmental threat posed globally (Vitousek et al. 1997).
The potential impact on the environment by invasive species regarded as ecosystem engineers, i.e. species with a disproportionate influence on ecosystem functionality that are considered pivotal in habitat creation, destruction and modification (Crooks 2002), is particularly great. Invasive plant species that generate gross changes in the vegetation of an area are often regarded as highly influential ecosystem engineers. Terrestrial examples of the impacts of such species are plentiful (see Crooks 2002 for review), whereas case studies in the marine environment are rarer and often confined to the intertidal zone, e.g. hybrids of the 
cordgrass Spartina spp. (Neira et al. 2005), the edible winkle Littorina littorea (Bertness 1984) and the green seaweed Codium fragile (Levin \& Hay 1996, Levin et al. 2002).

In the subtidal zone, submerged aquatic vegetation constitutes a functionally important component of many marine soft-sediment environments (Everett 1994). Vegetation such as seagrasses can profoundly influence animal assemblages by modification of physical, chemical and biological processes within these habitats (Everett 1994, Webster et al. 1998, Attrill et al. 2000, van Houte-Howes et al. 2004). For example, the physical presence of a plant canopy provides shelter and protection from predation for invertebrates and young fish (Summerson \& Peterson 1984, Stoner \& Lewis 1985, Edgar 1990, Boström \& Bonsdorff 1997, De Almeida \& Ruta 2000, Norkko et al. 2000, Jackson et al. 2001, Bloomfield \& Gillanders 2005). Vegetation also influences localised water flow (Fonseca \& Cahalan 1992, van Keulen \& Borowitzka 2002), which changes the sedimentation rate and can enhance sediment organic/nutrient content and food availability for infaunal and epifaunal communities (Hull 1987, Reusch \& Williams 1999). Consequently, vegetated habitats such as seagrass beds are typically characterised by high primary production, species diversity and faunal abundances (Webster et al. 1998, Bloomfield \& Gillanders 2005).

Marine angiosperms have been the subject of many ecological studies on subtidal vegetation (Hemmingga \& Duarte 2000). Much less is known about the influence of macroalgae that inhabit similar soft-sediment habitats, despite some of these species being abundant and clearly identifiable as potential ecosystem engineers. In Europe, few attached perennial macroalgae are associated with soft sediments. However, the invasive Japanese species Sargassum muticum, which was introduced into the UK in 1974 (Critchley et al. 1983), is an exception. Although restricted to hard substrata in many parts of its introduced European range (Stæhr et al. 2000), it also occupies extensive areas of subtidal soft sediments by growing in dense stands on embedded rock fragments and shells (Critchley 1983, Critchley et al. 1987). Due to its rare ability to colonise both hard and soft substrata, the total area of marine sediments open to occupation by $S$. muticum in Europe and North America is vast, and cumulative habitat modification could be very significant.

Once invasive Sargassum muticum has established a canopy over a previously unvegetated soft sediment substratum, there are 3 possible outcomes for the infaunal assemblages under this vegetation: (1) The canopy could reduce the diversity of infaunal and epifaunal communities, as do ephemeral algal blooms of Ulva (including Enteromorpha spp.; Hayden et al.
2003) that blanket soft substratum habitats (Soulsby et al. 1982, Everett 1994, Valiela et al. 1997, Raffaelli 2000); (2) it might enhance infaunal diversity in a similar fashion to other attached macroalgae (De Almeida \& Ruta 2000) and seagrasses; or (3) it might have no detectable effects on the communities. Furthermore, the effects of a particular invasion may change over time. Biological invasion theory (Williamson 1996) suggests that changes in the abundance of invaders can occur (i.e. they become 'equilibrated'), as observed in the pondweed Elodea canadensis (Elton 1958) and the zebra mussel Dreissena polymorpha (Magoulick \& Lewis 2002).

Intriguingly, adult Sargassum muticum are reported to be able to disperse within sediments, and further colonise them, by peripatetic 'stone-walking', i.e. peripheral movement induced when the buoyancy of the thallus exceeds the weight of the anchoring stone (Critchley 1981). The rapidly increasing geographical spread of $S$. muticum makes it one of the most striking marine introductions documented (Wallentinus 1999), yet few ecological aspects of the invasion have been investigated, and these only concern its occupation of hard substrata (e.g. Viejo 1997, Stæhr et al. 2000, Britton-Simmons 2004).

The main objective of the present study was to test the hypothesis that a canopy of invasive Sargassum muticum over soft sediment will affect infaunal communities in the same manner as macroalgal blooms, reducing diversity and abundance. We tested this hypothesis on both recently established populations (Strangford Lough, Northern Ireland, 5 yr after colonisation), and populations several decades after establishment (Langstone Harbour, southern England, colonised in 1974). Any effects of $S$. muticum canopies on the physical environment were determined in comparison to native macroalgal canopies, i.e. stands of Laminaria saccharina that can form over soft sediments when embedded stones are present. The potential ecological significance for soft-sediment communities in Europe and elsewhere was evaluated by addressing the dynamics of soft sediment habitat occupation, including peripatetic colonisation, by $S$. muticum in Strangford Lough at 2 spatial and temporal scales.

\section{MATERIALS AND METHODS}

Study sites. Strangford Lough, a large sea-lough with a narrow entrance, is situated on the east coast of Northern Ireland (Fig. 1). Sargassum muticum was first recorded in March 1995 at Paddy's Point on the northwestern shore (Fig. 1; Boaden 1995). During 1995, 1996, 1997 and 1998, manual clearance operations were undertaken by the Environment and Heritage 


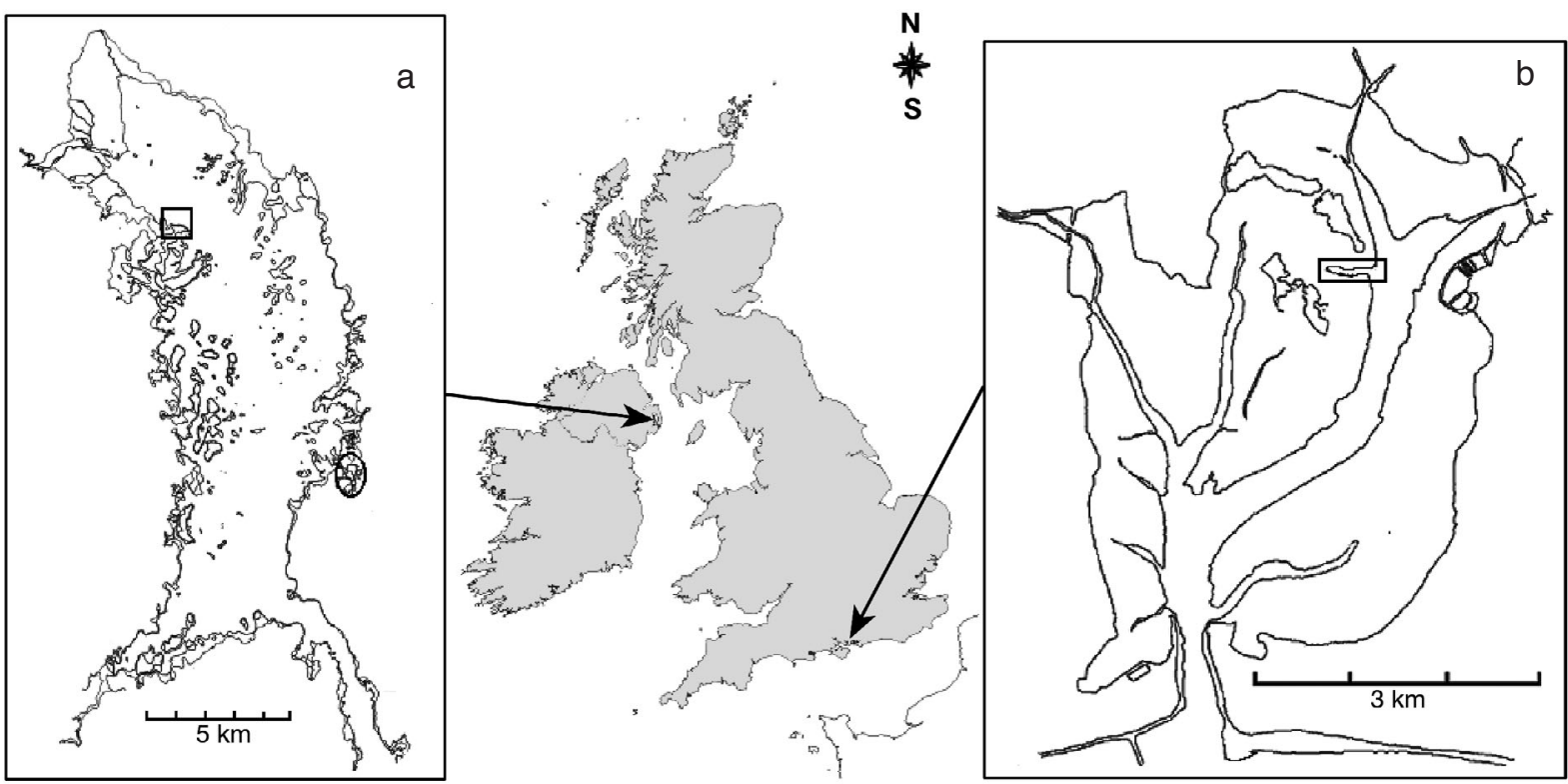

Fig. 1. (a) Strangford Lough, Northern Ireland. Inset square surrounds Paddy's Point $\left(54^{\circ} 32^{\prime} \mathrm{N}^{\prime} 005^{\circ} 35^{\prime} \mathrm{W}\right)$ and oval surrounds the Dorn $\left(54^{\circ} 26^{\prime} \mathrm{N}, 005^{\circ} 32^{\prime} \mathrm{W}\right)$. (b) Langstone Harbour, Portsmouth, England, redrawn from an Ordnance Survey map with inset rectangle surrounding Russell's Lagoon $\left(50^{\circ} 49.5^{\prime} \mathrm{N}, 001^{\circ} 00.05^{\prime} \mathrm{W}\right)$. Land and low water contours shown on both site maps

Service (EHS) Northern Ireland in an attempt to contain the invasion in this Special Area of Conservation (Davison 1999). The infaunal investigation was carried out at Paddy's Point and the study of peripatetic dispersal and modification of the physical environment was performed in a Marine Nature Reserve called the Dorn. This is an inlet on the south-eastern shore of the lough (Fig. 1) which was colonised by $S$. muticum in 1996 (Davison 1999).

Langstone Harbour, on the south coast of England (Fig. 1), is a large tidal bay between Hayling Island and Portsmouth. A narrow entrance protects the harbour from the open sea and small channels link Langstone with Portsmouth and Chichester Harbours. Sargassum muticum was first observed in this area in 1974 (Critchley et al. 1983). Russell's Lagoon was selected as the study site (Fig. 1) because it is the only area occupied by $S$. muticum that is shallow enough to sample at low tide without a boat.

Infaunal and sediment sampling. We randomly sampled 3 discrete stands $\left(>10 \mathrm{~m}^{2}\right)$ of Sargassum muticum at Paddy's Point (Strangford Lough) in August 2000. Sampling at Russell's Lagoon (Langstone Harbour) in July 2001was carried out in 3 discrete areas within the only continuous stand $\left(>100 \mathrm{~m}^{2}\right)$ of $S$. muticum. All of the sampled stands at both sites had similar densities of $S$. muticum thalli ( 45 to 60 plants $\mathrm{m}^{-2}$ ) and depth profiles $(0.2$ to $0.4 \mathrm{~m}$ below Mean Low Water of Spring Tides, MLWS). At each site, in each of the 3 S. muticum stands/areas, seven $110 \mathrm{~mm}$ diameter cores were hap- hazardly located and inserted into the sediment to a depth of $200 \mathrm{~mm}$ before being dug out. Haphazard sampling was considered not to introduce bias, as the feature of interest, i.e. the infaunal community, was not evident from the surface. Care was taken to avoid the vegetation and associated epiphytic fauna. From outside each stand/area, 7 infaunal and 7 sediment cores were taken at random points within a strip, at a distance of 1 to $2 \mathrm{~m}$ from the perimeter of the stand. The spacing between canopy and non-canopy cores and haphazard sampling follow established nested methods used for seagrass bed analysis (Webster et al. 1998, Frost et al. 1999). One infaunal sample from Russell's Lagoon was lost during sieving.

A sediment core (50 $\mathrm{mm}$ diameter) was taken in close proximity to each of the infaunal cores so that there were 21 under-canopy and 21 non-canopy cores at each of the 2 locations, Paddy's Point and Russell's Lagoon.

Laboratory analysis of infauna. Samples were sieved through a $500 \mu \mathrm{m}$ mesh, fixed in $10 \%$ formalin and stained with Rose Bengal (Eleftheriou \& Holme 1984). Macrofauna was sorted, identified to species level and enumerated using a dissecting microscope. One Strangford Lough canopy sample was lost. Individual biomass (wet weight) was obtained for each species by group weighing and then dividing by the number of individuals. The average body length was also determined for each species.

Sediment analysis. Granulometric analysis was performed using a Wentworth sieve series (-1.49 to $4.00 \phi)$ 
and median grain size $(\phi)$, sorting coefficient and silt/clay fraction (\%) calculated.

Data analysis. Spatial variation in infaunal community composition within each locality was minimal. There were no significant differences among stands/ areas within localities (1-way ANOSIM; Strangford Lough global $R=-0.016, \mathrm{p}=0.56$; Langstone Harbour, global $R=-0.022, \mathrm{p}=0.54)$. Therefore data from stands/areas within a locality were combined to facilitate a further 1-way ANOSIM to compare canopy versus non-canopy samples, after initial square root transformation of the species matrix. The ANOSIM tests were carried out in PRIMER (Plymouth Routines in Marine Ecological Research), a multivariate community analysis program (Clarke \& Gorley 2001). SIMPER analysis within PRIMER identified which species generate the most dissimilarity between 'treatments', and thereby highlights significant species substitutions between areas. For the SIMPER routine, the raw data were square root transformed and reporting was limited to species with more than $2.5 \%$ contribution to dissimilarity. The DIVERSE program within PRIMER was used to calculate the univariate community descriptive statistics.

The Infaunal Trophic Index (ITI) was also calculated for each sample and averaged according to factor and location. The purpose of the ITI is to describe the feeding behaviour of soft bottom benthic communities (Word 1979). Species are allocated to 1 of 4 groups based on whether species are suspension or deposit feeders and feed above/on or below the sediment surface. The ITI is calculated by determining the total abundance of the taxa belonging to each of the 4 groups and combining them in the following formula:

ITI $=100-\left\{33.33\left[\left(0 n_{1}+1 n_{2}+2 n_{3}+3 n_{4}\right) /\left(n_{1}+n_{2}+n_{3}+n_{4}\right)\right]\right\}$ where $n_{1}-n_{4}$ is the number of individuals of (1) suspension feeders, (2) surface detritus feeders, (3) surface deposit feeders and (4) sub-surface deposit feeders. The numerators in the ITI equation are scaling factors that link feeding categories to levels of organic matter in the sedimentary environment (Pearson \& Rosenberg 1978). The predominance of the ITI feeding category, reported as the 'dominant feeding guild', is considered to be indicative of the available organic material in the water and/or substratum (Cromey et al. 2002). The 'ITI score' ranges from 0 to 100 and results can be interpreted as follows: 60.0 to 100.0 , community 'normal'; 30.0 to 59.9, community 'changed'; 0.00 to 29.9, community 'degraded'. This functional index is one of the indices adopted by many national monitoring programmes, including the UK National Marine Monitoring Plan (see www.cefas.co.uk/monitoring/ page-b3.htm) to assess the biological quality of the benthic environment.
The univariate descriptive statistics and the sediment parameters were analysed with 1-way and 2-way ANOVA using SPSS (Statistical Package for the Social Sciences). DOMPLOT (DOMination PLOT) was used to construct Abundance/Biomass Curves (ABC) and to obtain the $W$ (Warwick) statistic. ABC plots are an extension of $k$-dominance curves as they include biomass data. The $W$ statistic describes the relationship between the cumulative abundance and biomass curves in the ABC plots (Clarke \& Warwick 1994).

Physical effects of canopy. During low tide periods in the Dorn, Strangford Lough, water continuously drains from the tidal pools into the channels. Within these channels, flow is unidirectional and consistent throughout its profile. The channels form natural flumes that were used to assess flow suppression and temperature stratification within stands of Sargassum muticum and the native kelp Laminaria saccharina. All macroalgal stands studied were at least $4 \mathrm{~m}$ in diameter (ground cover) and there was approximately $0.4 \mathrm{~m}$ of water at mean low water neaps - at this depth, much of the canopy vegetation was concentrated at the surface of the water. Water movement at low tide was measured with flow meters (model MFP51, Geopacks) upstream of and within canopies ( 0.2 to $0.3 \mathrm{~m}$ below the surface). Five replicated flow readings were collected at the same location at each point in the following sampling design. Inside the canopy, 7 points were haphazardly distributed $1 \mathrm{~m}$ in from the upstream margin of the stand. Outside the canopy, 7 points were haphazardly distributed $0.5 \mathrm{~m}$ upstream of the margin of the stand. The values were converted into percentage flow reduction and analysed with 1-way ANOVA.

Canopy temperature readings were taken $0.05 \mathrm{~m}$ under the water surface and sub-canopy values at the surface of the substratum, 0.3 to $0.4 \mathrm{~m}$ from the water surface. When placing any of the probes under a canopy, care was taken not to disturb the vegetation or agitate the water excessively. The probes were allowed to stabilise for $5 \mathrm{~min}$ before readings were taken.

Irradiance measurements were made using a photometer (Model Li-189, LI-COR) above and below the canopies of Sargassum muticum and Laminaria saccharina, and compared to an unvegetated area. Readings were taken on a cloudless day and in a sheltered site, and the order of sampling of different canopies was randomised to minimise the effects of variation in meteorological conditions. All light, temperature and flow measurements were collected on 16 July 2000 starting at 11:30 h GMT.

Substratum occupation by Sargassum muticum in Strangford Lough. Distributional surveys of $S$. muticum were carried out in 1996, 1998 and 2000 by EHS and in 2002 by us. The subtidal fringe of the entire lough 
shoreline was searched on foot or by boat and the length of shoreline occupied by $S$. muticum colonies was determined using either a hand-held GPS or map triangulation. The shore occupied by $S$. muticum has been expressed as a linear measure because this species is confined to a narrow vertical range in Strangford Lough. Based on original field documents and subsequent surveys, all the shoreline occupied by $S$. muticum was assigned to one of 3 types of substratum: (1) a predominantly soft substratum with $\leq 5 \%$ embedded loose rock; (2) mixed small loose rock on a mud/sand base; or (3) immobile bedrock, boulder or cobble substratum.

Peripatetic colonisation and dispersal. To establish the importance of peripatetic colonisation of new habitat, a $12 \mathrm{~m} \times 2 \mathrm{~m}$ subtidal section of the northern shore of the Dorn was marked and all Sargassum muticum thalli in it were counted and removed in June 2000. From June to October 2000, the number of peripatetic thalli found in the cleared area was counted weekly.

A second experimental plot was used to assess the dispersal range of peripatetic plants of Sargassum muticum in Strangford Lough. For this, we selected 2 sites in the Dorn. One site with a sandy substratum was exposed to strong tidal currents; the other was sheltered from currents, with a muddy sand substratum,
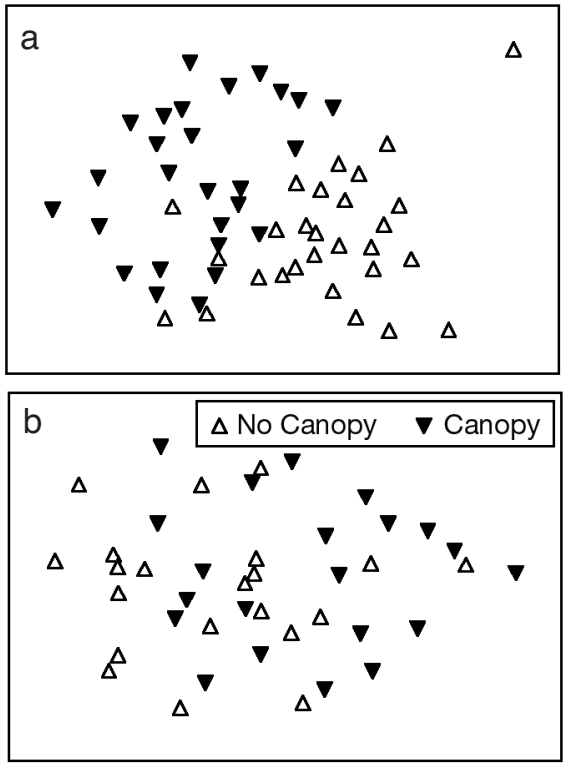

Fig. 2. Multidimensional scaling plot (PRIMER) for infaunal cores collected under $(\boldsymbol{\nabla})$ and outside $(\Delta)$ canopies of Sargassum muticum at (a) Paddy's Point, Strangford Lough (stress 0.21) and (b) Russell's Lake, Langstone Harbour (stress 0.15) and perpendicular to the first site. In May 2002, a random point was generated for both sites and marked with an angle-iron post. At each site the 30 individuals of $S$. muticum closest to the post, but not attached to bedrock, were individually numbered with slightly buoyant surface markers $\left(5 \mathrm{~cm}^{2}\right.$ bubble wrap squares: Aid-Pack). The floats were attached to the holdfast with fishing line and were small enough not to contribute to the drag or buoyancy of the peripatetic individuals. The peripatetic dispersal of each labelled individual from the initial start point was measured with a tape measure every $2 \mathrm{wk}$ for $2 \mathrm{mo}$, and all distances travelled are provided along with summary statistics (Table 8).

\section{RESULTS}

\section{Infaunal communities under and outside Sargassum muticum canopies in Strangford Lough}

Multivariate analysis of the species matrix revealed a significant difference between infaunal samples taken under and outside the canopies of Sargassum muticum (1-way, ANOSIM $n=20, p=0.038)$. This difference is highlighted by the MDS (multi-dimensional scaling) plot that shows the majority of unvegetated (no canopy) samples to the right of the plot and the majority of canopy samples clustered to the left of the plot (Fig. 2a). A relatively high level of overall dissimilarity between canopy and non-canopy samples (69.1\%) was found with the SIMPER analysis. Table 1 lists the species that contributed the greatest amount of dissimilarity between the treatments. The most numerically important were the juvenile bivalves (probably Modiolus modiolus) present in greater numbers under the canopy, whereas species such as the polychaetes 
Scoloplos armiger and Ophelia rathkei were more abundant outside the canopy (Table 1).

There were no differences in either the mean number of species or the abundance of individuals sampled from under and outside the canopies (Table 2). Several other characteristics differed significantly, however (Table 2). Samples taken from under a canopy were, on average, $20 \%$ lower for Shannon diversity and Pielou's evenness, but had a higher level of community dominance (Simpson's index). The mean body length of the infauna was almost twice as great outside than under a canopy (Table 2). The ABC for the canopy samples generated a negative $W$ statistic (Table 2), i.e. the cumulative abundance curve (not shown) was well above the cumulative biomass curve. For samples from outside the canopy the $\mathrm{ABC}$ for cumulative abundance was just above the biomass curve, so that the $W$ statistic was positive.

Table 2. Descriptive community statistics and sediment characteristics (mean \pm $\mathrm{SD})$ for core samples taken under $(\mathrm{n}=20)$ and outside $(\mathrm{n}=21)$ canopies of Sargassum muticum in Strangford Lough. Data analysed using 1-way ANOVA. Dominant feeding guild: (1) suspension feeders, (2) surface detritus feeders, (3) surface deposit feeders and (4) sub-surface deposit feeders

\begin{tabular}{|lcccr|}
\hline Parameter & $\begin{array}{c}\text { Under } \\
\text { canopy }\end{array}$ & $\begin{array}{c}\text { Outside } \\
\text { canopy }\end{array}$ & $\mathrm{p}$ & $F$ \\
\hline Total species & $15.03 \pm 3.6$ & $15.39 \pm 4.7$ & 0.780 & 0.079 \\
Total abundance (ind.) & $160.54 \pm 209.35$ & $86.36 \pm 74.4$ & 0.071 & 3.384 \\
Shannon diversity & $1.84 \pm 0.57$ & $2.17 \pm 0.25$ & 0.006 & 8.052 \\
Pielou's evenness & $0.69 \pm 0.22$ & $0.81 \pm 0.60$ & 0.008 & 7.594 \\
Simpson's dominance index & $0.29 \pm 0.21$ & $0.17 \pm 0.04$ & 0.005 & 8.447 \\
Infaunal Trophic Index score & 54.21 & 34.42 & 0.001 & 12.579 \\
Dominant feeding guild & 2.52 & 3.12 & 0.010 & 7.126 \\
Mean body length (mm) & $8.06 \pm 4.73$ & $15.64 \pm 7.04$ & 0.000 & 22.631 \\
$W$ statistic & $-0.095 \pm 0.13$ & $0.072 \pm 0.23$ & 4.259 & 5.568 \\
Median grain size $(\phi)$ & $1.82 \pm 0.22$ & $1.81 \pm 0.27$ & 0.866 & 0.029 \\
Sorting coefficient & $0.72 \pm 0.23$ & $0.79 \pm 0.23$ & 0.312 & 1.052 \\
Silt/clay fraction $(\%)$ & $0.63 \pm 0.45$ & $0.78 \pm 0.62$ & 0.371 & 0.819 \\
& & & & \\
\hline
\end{tabular}

Table 3. SIMPER analysis (in PRIMER) of the infaunal assemblages under and outside a canopy of Sargassum muticum in Russell's Lagoon, Langstone Harbour, with dissimilarity cut-off set at $2.5 \%$ (square root transformation used for analysis). Abundance expressed as individuals per core; values in parentheses are \% contribution to within-treatment similarity

\begin{tabular}{|c|c|c|c|}
\hline \multirow[t]{2}{*}{ Species } & \multicolumn{2}{|c|}{ Mean abundance } & \multirow{2}{*}{$\begin{array}{c}\text { Contribution to } \\
\text { dissimilarity } \\
(\%)\end{array}$} \\
\hline & $\begin{array}{l}\text { Under } \\
\text { canopy }\end{array}$ & $\begin{array}{l}\text { Outside } \\
\text { canopy }\end{array}$ & \\
\hline Cirriformia tentaculata & $162.81(41.71)$ & $104.05(49.80)$ & 22.66 \\
\hline Tubificoides pseudogaster & $27.14(7.19)$ & $18.00(7.20)$ & 12.00 \\
\hline Tubificoides bendini & $31.67(9.22)$ & $21.33(9.10)$ & 10.94 \\
\hline Corophium sp. & $3.52(0.62)$ & $1.67(0.47)$ & 6.48 \\
\hline Capitellides giardi & $2.67(0.19)$ & $1.38(0.34)$ & 6.48 \\
\hline Capitella capitata & $1.86(0.18)$ & $0.43(0.07)$ & 4.89 \\
\hline Terebellid & $1.05(0.09)$ & $0.67(0.09)$ & 4.21 \\
\hline
\end{tabular}

The dominant feeding guild calculated from the ITI alysis indicated that both surface detritus feeders surface deposit feeders were equally abundant face deposit feeders. Samples from under and outsic the canopy were classified by the ITI score as having been collected from a 'changed' community.

\section{Infaunal communities under and outside Sargassum muticum canopies in Langstone Harbour}

There was a significant difference between macro-inever, SIMPER analysis reported a relatively low level of dissimilarity $(32.7 \%)$ between canopy and non-canopy samples. This dissimilarity appeared to be driven by a consistently higher animal abundance under the canopy than outside (Table 3). The MDS plot shows only slight separation of canopy and non-canopy samples (Fig. 2b).

Univariate analysis of the communities indicated that infaunal samples from under the canopy contained significantly more individuals (Table 4). No other univariate community statistic differed significantly between treatments and the $W$ statistics obtained from $A B C$ plots did not differ either (Table 4). Surface deposit feeders were the dominant trophic guild in both vegetated and unvegetated samples.

\section{Sediment characteristics}

Sediment composition (median size, sorting or silt/clay fraction) was not affected by the presence of a canopy of Sargassum muticum in either Strangford Lough (Table 2) or Langstone Harbour (Table 4).

\section{Modification of physical environment by macroalgal canopies}

In an unvegetated habitat, $89 \%$ of sub-surface irradiance penetrated to the substratum at low tide (depth $0.35 \mathrm{~m}$ ), whereas under algal canopies this value was less than $5 \%$ (Table 5). 
Table 4. Descriptive statistics for the community structure and sediment characteristics (mean $\pm \mathrm{SD})$ under $(\mathrm{n}=21)$ and outside $(\mathrm{n}=21)$ a canopy of Sargassum muticum in Russell's Lagoon, Langstone Harbour. Data analysed using 1-way ANOVA. Dominant feeding guild: (1) suspension feeders, (2) surface detritus feeders, (3) surface deposit feeders and (4) sub-surface deposit feeders

\begin{tabular}{|lcccc|}
\hline Parameter & $\begin{array}{c}\text { Under } \\
\text { canopy }\end{array}$ & $\begin{array}{c}\text { Outside } \\
\text { canopy }\end{array}$ & $\mathrm{p}$ & $F$ \\
\hline Total species & $8.62 \pm 2.71$ & $7.48 \pm 2.06$ & 0.132 & 2.363 \\
Total abundance (ind.) & $235.19 \pm 133.89$ & $151.43 \pm 103.27$ & 0.029 & 5.153 \\
Shannon diversity & $1.00 \pm 0.28$ & $0.99 \pm 0.22$ & 0.906 & 0.014 \\
Pielou's evenness & $0.47 \pm 0.11$ & $0.51 \pm 0.10$ & 0.328 & 0.981 \\
Simpson's dominance index & $0.48 \pm 0.08$ & $0.48 \pm 0.06$ & 0.976 & 0.001 \\
Infaunal Tropic Index score & 46.82 & 47.71 & 0.736 & 0.115 \\
Dominant feeding guild (ITI) & 2.95 & 2.95 & 0.999 & 0.000 \\
Mean body length (mm) & $121.72 \pm 24.48$ & $124.42 \pm 16.87$ & 0.727 & 0.124 \\
$W$ statistic & $0.14 \pm 1.23$ & $0.13 \pm 1.23$ & 0.896 & 0.017 \\
Median grain size $(\phi)$ & $3.20 \pm 1.23$ & $2.84 \pm 1.30$ & 0.721 & 0.130 \\
Sorting coefficient & $4.30 \pm 1.32$ & $3.76 \pm 1.29$ & 0.162 & 2.087 \\
Silt/clay fraction $(\%)$ & $3.28 \pm 0.83$ & $3.19 \pm 0.99$ & 0.806 & 0.061 \\
\hline
\end{tabular}

Table 5. Irradiance (mean $\pm \mathrm{SD}$ ) and its attenuation under 2 species of macroalgae and in an unvegetated area in the Dorn, Strangford Lough (moderately sunny day without cloud cover in June 2000). Superscript letters indicate significantly different (ANOVA, 1 -way, $\mathrm{p}<0.001 ; F_{4,150}=7016.191$ ) sub-groups as identified by a Tukey-Kramer test; na: not applicable

\begin{tabular}{|c|c|c|}
\hline Sensor location (depth) & $\begin{array}{l}\text { Mean irradiance } \\
\pm \mathrm{SD}(\mu \mathrm{mol} \\
\left.\text { photons } \mathrm{m}^{-2} \mathrm{~s}^{-1}\right)\end{array}$ & $\begin{array}{l}\text { Light absorption } \\
\text { relative to unvegetated } \\
\text { near-surface value }(\%)\end{array}$ \\
\hline Out of water $(n=35)$ & $2595 \pm 3.7$ & na \\
\hline $\begin{array}{l}\text { Unvegetated area }(\mathrm{n}=35) \text {; near } \\
\text { surface }(0.15 \mathrm{~m})\end{array}$ & $1129 \pm 1.2^{\mathrm{a}}$ & na \\
\hline $\begin{array}{l}\text { Unvegetated area }(\mathrm{n}=35) ; \text { at } \\
\text { substratum }(0.35 \mathrm{~m})\end{array}$ & $1008 \pm 9.1^{b}$ & 10.7 \\
\hline $\begin{array}{l}\text { Laminaria saccharina stand }(\mathrm{n}=35) \text {; } \\
\text { at substratum }(0.35 \mathrm{~m})\end{array}$ & $49 \pm 9.8^{c}$ & 95.6 \\
\hline $\begin{array}{l}\text { Sargassum muticum stand }(\mathrm{n}=15) ; \\
\text { at substratum }(0.35 \mathrm{~m})\end{array}$ & $31 \pm 8.9^{d}$ & 97.2 \\
\hline
\end{tabular}

Canopies of Sargassum muticum absorbed $97.2 \%$ of the sub-surface irradiance, compared to $95.6 \%$ for Laminaria saccharina canopies $(\mathrm{p}<0.001)$ (Table 5). Suppression of current flow by $S$. muticum was not significantly different from that by L. saccharina (Table 6). A $2{ }^{\circ} \mathrm{C}$ warming was apparent in the canopy of L. saccharina when compared to the ambient seawater in unvegetated areas. Warming within the canopy of $S$. muticum was much greater, with the water temperature elevated by $11^{\circ} \mathrm{C}$ above ambient. Unlike for L. saccharina canopies, evidence of a significant cooling to $2^{\circ} \mathrm{C}$ below ambient was observed under the canopy of $S$. muticum.

\section{Substratum occupation by Sargassum muticum in Strangford Lough}

The total shoreline colonised by Sargassum muticum lengthened from 0.61 $\mathrm{km}$ in 1996 to $12.86 \mathrm{~km}$ in 1998 (Table 7). This increase was mainly due to a greater occupation of habitats with loose rock on a soft sediment base. From 1998 to 2000 , although the colonised shoreline increased more than 3 -fold, the relative proportions of each substratum type remained the same, $97 \%$ of the occupied shoreline being mobile, soft substrata. Between 2000 and 2002, the length of shoreline occupied decreased by nearly $50 \%$, mostly by loss from soft rather than hard substrata. Despite this, $93 \%$ of the shoreline occupied was still loose rock on soft sediment (Table 7 ).

Table 6. Flow suppression and thermal stratification within canopies of Sargassum muticum and Laminaria saccharina, based on 15 measurements under each condition. T: temperature; F: flow. ${ }^{*}$ Data analysed using 1-way ANOVA where applicable; na: not applicable; nd: no data

\begin{tabular}{|c|c|c|c|c|c|c|c|}
\hline & \multirow{2}{*}{$\begin{array}{l}\text { Sensor } \\
\text { depth } \\
(\mathrm{m})\end{array}$} & \multicolumn{3}{|c|}{$\begin{array}{c}\text { Reduction in water } \\
\text { velocity }(\%)\end{array}$} & \multicolumn{3}{|c|}{ Temperature $\left({ }^{\circ} \mathrm{C}\right)$} \\
\hline & & Mean $\pm \mathrm{SD}$ & $\mathrm{p}$ & $F_{1,14}$ & Mean \pm SD & $\mathrm{p}$ & $F_{1,14}$ \\
\hline Unvegetated areas at surface & 0.05 & na & & & $12 \pm 0.4$ & & \\
\hline Within Laminaria saccharina canopy & T: $0.05 ;$ F: 0.30 & $74.6 \pm 26.8$ & 0.419 & $0.717^{*}$ & $14 \pm 3.1$ & 0.016 & $6.639^{*}$ \\
\hline $\begin{array}{l}\text { Below Laminaria saccharina canopy; } \\
\text { at substratum surface }\end{array}$ & 0.35 & nd & & & $12 \pm 0.6$ & 0.432 & $0.634^{*}$ \\
\hline Within Sargassum muticum canopy & T: $0.05 ;$ F: 0.30 & $84.0 \pm 39.7$ & 0.115 & 0.736 & $23 \pm 5.0$ & $<0.001$ & $151.536^{*}$ \\
\hline $\begin{array}{l}\text { Below Sargassum muticum canopy; } \\
\text { at substratum surface }\end{array}$ & 0.35 & nd & & & $10 \pm 0.7$ & $<0.001$ & $260.693^{*}$ \\
\hline
\end{tabular}


Table 7. Substratum type colonised by Sargassum muticum in Strangford Lough, Northern Ireland, in 1996, 1998, 2000 and 2002

\begin{tabular}{|c|c|c|c|c|}
\hline \multirow[t]{2}{*}{ Substratum } & \multicolumn{4}{|c|}{$\begin{array}{l}\text { Length in } \mathrm{km} \text { of shore colonised } \\
\text { (\% shoreline with substratum type) }\end{array}$} \\
\hline & 1996 & 1998 & 2000 & 2002 \\
\hline $\begin{array}{l}\text { Predominantly soft } \\
\text { substratum with } \leq 5 \% \\
\text { embedded loose rock }\end{array}$ & $\begin{array}{l}0.46 \\
(76)\end{array}$ & $\begin{array}{l}2.27 \\
(18)\end{array}$ & $\begin{array}{l}7.66 \\
(16)\end{array}$ & $\begin{array}{c}0.53 \\
(0.02)\end{array}$ \\
\hline $\begin{array}{l}\text { Mixed small loose } \\
\text { rock on mud/sand } \\
\text { base }\end{array}$ & $\begin{array}{l}0.15 \\
(24)\end{array}$ & $\begin{array}{c}10.17 \\
(79)\end{array}$ & $\begin{array}{c}38.78 \\
(81)\end{array}$ & $\begin{array}{c}26.60 \\
(93)\end{array}$ \\
\hline $\begin{array}{l}\text { Immobile bedrock, } \\
\text { boulder and cobble } \\
\text { substratum }\end{array}$ & $\begin{array}{c}0 \\
(0)\end{array}$ & $\begin{array}{c}0.42 \\
(3)\end{array}$ & $\begin{array}{c}1.44 \\
(3)\end{array}$ & $\begin{array}{l}1.37 \\
(5)\end{array}$ \\
\hline $\begin{array}{l}\text { Total length of } \\
\text { subtidal fringe } \\
\text { colonised }(\mathrm{km})\end{array}$ & 0.61 & 12.86 & 47.88 & 28.5 \\
\hline
\end{tabular}

\section{Peripatetic colonisation in the Dorn, Strangford Lough}

The results summarised here are for the experiment concerning recolonisation of a cleared patch. In the monitored $24 \mathrm{~m}^{2}$ subtidal section of the Dorn, the density of Sargassum muticum thalli before clearance in June 2000 was 14.48 plants $\mathrm{m}^{-2}$. After 2 mo, a mean of 6.20 peripatetic thalli $\mathrm{m}^{-2}$ had moved into the cleared site, replacing nearly half of the individuals removed. All of the newly arrived thalli within the cleared area were reproductive. At the end of September, the number of accumulated peripatetic thalli declined rapidly; field observations indicated that stormy weather was causing individuals to be stranded higher up the shore.

Determination of the distances travelled by peripatetic thalli showed that at sites characterised both by high (Site A) and low (Site B) water motion, the majority of plants remained stationary (Table 8). For those that did move, the average distances travelled at the 2 sites were similar, i.e. $4.2 \mathrm{~m}$ at Site A and $2.2 \mathrm{~m}$ at Site B. The maximum dispersal recorded at both sites was $34 \mathrm{~m}$ and all of the peripatetic movement was in one direction along the shore, corresponding to the residual tidal currents in the Dorn. Approximately 9 to $12 \%$ of the individuals were lost, either because they moved outside the study area or were cast up on the strandline.

\section{DISCUSSION}

\section{Effects of macroalgal canopies on infaunal communities}

Univariate indices and multivariate community analysis of the infauna revealed significant differences between the assemblages under and outside canopies of Sargassum muticum in both Strangford Lough and Langstone Harbour. In Strangford Lough, the infaunal community under a canopy of Sargassum muticum was of a lower diversity and was characterised by a greater abundance of numerically dominant small organisms than the non-canopy community. The negative $W$ statistic and the finding that many of the abundant species (e.g. Tubificoides pseudogaster and Capitellides giardi) under the canopy are opportunistic $r$-selected species (Pearson \& Rosenberg 1978) also reflected the predominance of small yet abundant species. Furthermore, the greater dominance of surface detritus feeders under these conditions is consistent with the localised primary production.

The larger body size in the non-canopy community is an indicator of a stable habitat, in which disturbance is infrequent and the infauna are skewed towards $K$-selected strategies. $K$-selected species are rarely numerically dominant, but are foremost in terms of biomass (Clarke \& Warwick 1994). When a community is perturbed, $K$-selected species are less favoured, and opportunistic $r$-selected species quickly proliferate (Clarke \& Warwick 1994), so the enhancement of $r$ selected species below the canopy suggests that this assemblage was under some form of 'stress'. These results therefore support the hypothesis that a newly established canopy of the invasive macroalga Sargassum muticum will reduce the diversity and abundance of infaunal communities under this vegetation.

In Langstone Harbour, the differences observed between assemblages under and outside the canopy were fundamentally distinct to those found in Strangford Lough. Under the canopy, species composition remained the same and yet abundance increased substantially, which did not change the assemblage diversity, dominance, community trophic status or evenness between canopy and unvegetated areas.

Table 8. Sargassum muticum. Dispersal (distance from initial position, m) of peripatetic macroalgae over a 2 mo period in high tidal flow (Site A) and low tidal flow (Site B) habitats in the Dorn, Strangford Lough. Data analysed using 1-way ANOVA; $\mathrm{p}=0.344, F_{1,40}=0.918$

\begin{tabular}{|lcccccccc|}
\hline & $<0.5$ & $0.5-0.9$ & $1.0-4.9$ & $5.0-15.0$ & $15.1-30.0$ & $>30.0$ & Lost & Mean \pm SD \\
\hline Site A & 13 & 1 & 4 & 0 & 0 & 2 & 2 & $4.23 \pm 9.97$ \\
Site B & 18 & 2 & 1 & 0 & 0 & 1 & 3 & $2.23 \pm 7.13$ \\
\hline
\end{tabular}


Within the present study, evidence from separate locations both supports and opposes the initial hypothesis that a canopy of invasive Sargassum muticum over soft sediment will decrease the diversity and abundance of infaunal communities. Therefore the generality of the initial premise for both sites must be rejected. In Strangford Lough, the less diverse infaunal assemblage under the canopy suggests that some aspect of the introduced vegetation, either directly or indirectly, perturbs this community. By contrast, the Langstone Harbour infaunal community showed no signs of perturbation; rather, the presence of a canopy of $S$. muticum appeared to have enhanced the faunal abundance of the resident assemblage. It is clear that the presence of $S$. muticum does influence infaunal communities. However, perhaps due to site-specific differences between Paddy's Point and Russell's Lagoon, such as the smaller particle size, increased sorting and silt/clay fraction at the latter and other biotic and abiotic factors, the influence of this introduced vegetation can vary. The differing particle size at the 2 sites will undoubtedly result in differing infaunal composition, but it is the differences within a site between vegetated and unvegetated areas that are interesting in highlighting localised responses of the infaunal assemblages to $S$. muticum. The duration of occupation by $S$. muticum may be another factor. In Langstone Harbour, S. muticum has been present since 1974, providing more time for the native assemblages to potentially adapt to and ultimately exploit the presence of, and processes associated with, this species.

Our findings have several features in common with those of Neira et al. (2005), who examined the impact of hybrid invasive Spartina spp. at 3 intertidal areas in San Francisco Bay. As with the present study, changes in the infaunal community between vegetated and unvegetated areas differed between sites. The reason for the lack of consistency was related to either the duration of Spartina spp. occupation at the sites (ranging from 10 to $30 \mathrm{yr}$ ) or specific differences in the topography and sediment mediating the presence of Spartina spp. in differing ways. In accordance with the conclusions of Neira et al. (2005), only continuing temporal surveillance in Strangford Lough can test whether the impact of invasive species declines with time.

\section{Influences of vegetation on the physical environment}

One of the objectives of our study was to elucidate the causes of any changes in the infauna by establishing whether Sargassum muticum had modified the physical environment. The finding that sediment parti- cle size characteristics did not differ between canopy and non-canopy habitats at either Strangford Lough or Langstone Harbour is surprising considering that there was strong flow suppression. However, unlike S. furcatum and seagrass communities, which show similar levels of water baffling but modify associated sediments (De Almeida \& Ruta 2000, van Keulen \& Borowitzka 2002), S. muticum sheds its canopies annually, leaving only the perennial holdfasts. This cycle leaves the sediment exposed for approximately 4 to 5 mo each year, during which time wave action and currents could re-suspend and remove sediment accumulated in the vegetated phase. The effects on infauna associated with the presence of invasive algal canopies in Strangford Lough were therefore not due to changes in sediment characteristics.

The canopy of Sargassum muticum had major effects on other aspects of the local environment, however. It had a strong shading effect, as previously observed (Critchley et al. 1990, Curiel et al. 1998), significantly greater than the native Laminaria saccharina. When one considers that in a native canopy less than $5 \%$ of the light reaches the sub-canopy, the extra $2 \%$ absorption by $S$. muticum actually represents an approximate $40 \%$ loss of the available light for the sub-canopy macroalgae.

Stands of Sargassum muticum in Strangford Lough caused strong temperature stratification including significant cooling of the water just above the sediment, as recorded in Lake Grevelingen, The Netherlands (Critchley et al. 1990). The extreme heating of the water associated with the surface canopy is typically restricted to a thin layer at the very surface of the water. Within the sheltered environment of Strangford Lough, the high density of $S$. muticum tends to prevent the water within the stands of vegetation from being exchanged with non-canopy areas. In addition, the dark colour of the canopy absorbs much of the light, and on a sunny day the stagnant water can become extremely warm. Such stratification did not occur in Laminaria saccharina beds, perhaps due to the lower standing biomass and because the vegetation does not 'interlock' as it does for $S$. muticum.

The temperature stratification documented in canopies of Sargassum muticum raises some interesting questions about the interaction of the warming and the physiology of this species. Norton (1977) found that the optimum temperature for growth of $S$. muticum was $25^{\circ} \mathrm{C}$, and that this species was also tolerant of temperatures up to $30^{\circ} \mathrm{C}$. One could hypothesize that this localised warming within the canopy might actually benefit $S$. muticum and increase its growth rate. Bouts of increased warming within the canopy may also have an impact on the extent of epiphytic colonisation by less tolerant species, for example by reducing the 
fouling burden on $S$. muticum. To what extent the temperature stratification and flow suppression/water exchange persist over a tidal cycle and the implications of these factors for the infaunal community may form hypotheses for future work.

\section{Occupation of soft-sediment habitats}

Clearly, peripatetic dispersal ('stone-walking') is unlikely to be a significant factor in reported range extensions in Sargassum muticum of 10 to $45 \mathrm{~km} \mathrm{yr}^{-1}$ (Wallentinus 1999). However, in Strangford Lough, peripatetic dispersal contributes significantly to the rapid consolidation and, hence, invasiveness of this species. In the sheltered confines of Strangford Lough, the mean distance travelled (about $3 \mathrm{~m}$ in $2 \mathrm{mo}$ ) was not great, yet the quantity of peripatetic individuals was large enough to repopulate half of the original density in cleared sites after just 2 mo. Plants that stone-walked between July and September were reproductive and releasing propagules, so even if they were lost from favourable habitat after storm events, the released germlings ensured that the site would still be invaded. Since its first appearance in Strangford Lough 5 yr before, $S$. muticum had colonised nearly $50 \mathrm{~km}$ of shoreline, most of it consisting of small loose rock on a muddy sand base not previously occupied by macroalgae. Peripatetic dispersal during the growing season is also involved in the spread of the highly invasive Codium fragile subspecies tomentosoides (Ben-Avraham 1971, Dromgoole 1990).

\section{Implications for soft-sediment communities in Europe}

Sargassum muticum has successfully invaded 12 European coastal countries and produced a nearcontinuous distribution from Sweden to Portugal, including the British Isles, and into the Mediterranean Sea (Wallentinus 1999). The process of colonisation also continues into Pacific North America and the southern hemisphere. The unusual ability to colonise predominantly soft substrata has undoubtedly allowed this species to spread quickly, become extremely abundant and hence develop sufficient biomass to qualify as an ecosystem engineer and generate significant habitat modification.

Although often overlooked when considering the environmental impact of Sargassum muticum, the extensive colonisation of unvegetated soft-sediment habitats has both generated a new epibenthic habitat and modified the resident infaunal assemblages at 2 contrasting study sites. Interestingly, the resulting influence of this species was found to differ between sites, ranging from a strong perturbation to a moderate enhancement of infaunal density. This could suggest that strong site-specific effects of $S$. muticum make generalizations about the impact of this species difficult. Nonetheless, the possibility that the long-term residence of $S$. muticum changes the nature of the influence of this species cannot be excluded. Continued surveillance within Strangford Lough could establish whether site-specific differences or the duration of colonisation is more important for determining the nature of habitat modification.

Acknowledgements. We thank Ciara Hetherington and Anna Leach for their assistance during fieldwork, and Mark Johnson for advice on statistics. This work was undertaken as part of a CAST PhD funded by the Department of Education (Northern Ireland) and the Environment and Heritage Service (Northern Ireland).

\section{LITERATURE CITED}

Attrill MJ, Strong JA, Rowden AA (2000) Are macroinvertebrate communities influenced by seagrass structural complexity? Ecography 23:114-121

Ben-Avraham Z (1971) Accumulation of stone on beaches by Codium fragile. Limnol Oceanogr 16:553-555

Bertness MD (1984) Habitat and community modification by an introduced herbivorous snail. Ecology 65:370-381

Bloomfield AL, Gillanders BM (2005) Fish and invertebrate assemblages in seagrass, mangrove, saltmarsh and nonvegetated habitats. Estuaries 28:63-77

Boaden PJS (1995) The adventive seaweed Sargassum muticum in Strangford Lough, County Down. Ir Nat J 27: 111-113

Boström B, Bonsdorff E (1997) Community structure and spatial variation of benthic invertebrates associated with Zostera marina (L.) beds in the northern Baltic Sea. J Sea Res 37:153-166

Britton-Simmons KH (2004) Direct and indirect effects of the introduced alga, Sargassum muticum (Yendo), in subtidal kelp communities of Washington State, USA. Mar Ecol Prog Ser 277:61-78

Clarke KR, Gorley RN (2001) PRIMER v5 user manual and tutorial. PRIMER-E, Plymouth

Clarke KR, Warwick RM (1994) Change in marine communities: an approach to statistical analysis and interpretation. PRIMER manual. Natural Environment Research Council, Annual Report. NERC, Swindon

Critchley AT (1981) Observations on the colonisation of Warden Point, Isle of Wight, by the introduced brown alga, Sargassum muticum (Yendo) Fensholt. Phycologia 20:102

Critchley AT (1983) The establishment and increase of Sargassum muticum (Yendo) Fensholt populations within the Solent area of southern Britain. II. An investigation of the increase in canopy cover of the alga at low water. Bot Mar 26:547-552

Critchley AT, Farnham WF, Morrell SL (1983) A chronology of new European sites of attachment for the invasive brown alga, Sargassum muticum, 1973-1981. J Mar Biol Assoc UK 63:799-811

Critchley AT, Nienhuis PH, Verschuure K (1987) Presence and development of populations of the introduced brown 
alga Sargassum muticum in the south west Netherlands. Hydrobiologia 151/152:245-255

Critchley AT, de Visscher RPM, Nienhuis PH (1990) Canopy characteristics of the brown alga Sargassum muticum in Lake Grevelingen, south west Netherlands. Hydrobiologia 204/205:211-217

Cromey CJ, Nickell TD, Black KD (2002) DEPOMOD-modelling the deposition and biological effects of waste solids from marine cage farms. Aquaculture 214:211-239

Crooks JA (2002) Characterizing ecosystem-level consequences of biological invasions: the role of ecosystem engineers. Oikos 97:153-166

Curiel D, Bellemo G, Marzocchi M, Scattolin M, Parisi G (1998) Distribution of introduced Japanese macroalgae Undaria pinnatifida, Sargassum muticum and Antithamnion pectinatum in the Lagoon of Venice. Hydrobiologia 385:17-22

Davison DM (1999) Sargassum muticum in Strangford Lough, 1995-1998; a review of the introduction and colonization of Strangford Lough MNR (Marine Nature Reserve) and cSAC (candidate Special Area of Conservation) by the invasive brown alga Sargassum muticum. Environment and Heritage Service Research and Development Series 99/27:1-84

De Almeida TCM, Ruta C (2000) Effects of a subtidal macroalgae bed on soft-bottom polychaete assemblages in Arraial do Cabo, Rio de Janeiro, Brazil. Bull Mar Sci 67:199-207

Dromgoole FI (1990) Gas-filled structures, buoyancy and support in marine macroalgae. Prog Phycol Res 7:169-211

Edgar GJ (1990) The influence of plant structure on the species richness, biomass and secondary production of macrofaunal assemblages associated with Western Australian seagrass. J Exp Mar Biol Ecol 137:215-240

Eleftheriou A, Holme NA (1984) Macrofauna techniques. In: Holm NA, McIntyre AD (eds) Methods for the study of marine benthos. Blackwell Scientific, Oxford, p 140-216

Elton GJ (1958) The ecology of invasions by animals and plants. Methuen, London

Everett RA (1994) Macroalgae in marine soft-sediment communities: effects on benthic faunal assemblages. J Exp Mar Biol Ecol 175:253-274

Fonseca MS, Cahalan JA (1992) A preliminary evaluation of wave attenuation by 4 species of seagrass. Estuar Coast Shelf Sci 35:565-576

Frost MT, Rowden AA, Attrill MJ (1999) Effect of habitat fragmentation on the macroinvertebrate infaunal communities associated with the seagrass Zostera marina L. Aquat Conserv 9:255-263

Hayden HS, Blomster J, Maggs CA, Silva PC, Stanhope MJ, Waaland JR (2003) Linnaeus was right all along: Ulva and Enteromorpha are not distinct genera. Eur J Phycol 38: $277-294$

Hemmingga MA, Duarte CM (2000) Seagrass ecology. Cambridge University Press, Cambridge

Hull SC (1987) Macroalgal mats and species abundance-a field experiment. Estuar Coast Shelf Sci 25:519-532

Jackson EL, Rowden AA, Attrill MJ, Bossey SJ, Jones MB (2001) The importance of seagrass beds as a habitat for fishery species. Oceanogr Mar Biol Annu Rev 39:269-303

Levin PS, Hay ME (1996) Responses of temperate reef fishes to alterations in algal structure and species composition. Mar Ecol Prog Ser 134:37-47

Levin PS, Coyer JA, Petrik R, Good TP (2002) Communitywide effects of nonindigenous species on temperate rocky reefs. Ecology 83:3182-3193

Magoulick DD, Lewis LC (2002) Predation on exotic zebra mussels by native fishes: effects on predator and prey. Freshw Biol 47:1908-1918

Neira C, Levin LA, Grosholz ED (2005) Benthic macrofaunal communities of three sites in San Francisco Bay invaded by hybrid Spartina, with comparison to uninvaded habitats. Mar Ecol Prog Ser 292:111-126

Norkko J, Bonsdorff E, Norkko A (2000) Drifting algal mats as an alternative habitat for benthic invertebrates: species specific responses to a transient resource. J Exp Mar Biol Ecol 248:79-104

Norton TA (1977) The growth and development of Sargassum muticum (Yendo) Fensholt. J Mar Biol Assoc UK 57:33-43

Pearson EC, Rosenberg L (1978) Macrobenthic succession in relation to organic enrichment and pollution of the marine environment. Oceanogr Mar Biol Annu Rev 16:229-311

Raffaelli DG (2000) Interactions between macro-algal mats and invertebrates in the Ythan estuary, Aberdeenshire, Scotland. Helgol Meersunters 54:71-79

Reusch TBH, Williams SL (1999) Macrophyte canopy structure and the success of an invasive marine bivalve. Oikos 84:398-416

Soulsby PG, Lowthion D, Houston M (1982) Effects of macroalgal mats on the ecology of inter-tidal mudflats. Mar Pollut Bull 13:162-166

Stæhr PA, Pederen MF, Thomsen MS, Wernberg, KrauseJensen D (2000) Invasion of Sargassum muticum in Limfjorden (Denmark) and its possible impact on the indigenous macroalgal community. Mar Ecol Prog Ser 70:79-88

Stoner AW, Lewis FG III (1985) The influence of quantitative and qualitative aspects of habitat complexity in tropical sea-grass meadows. J Exp Mar Biol Ecol 94:19-40

Summerson HC, Peterson CH (1984) Roles of predation in organising benthic communities of a temperate-zone seagrass bed. Mar Ecol Prog Ser 15:63-77

Valiela I, McClelland J, Hauxwell J, Behr PJ, Hersh D, Foreman K (1997) Macroalgal blooms in shallow estuaries: controls and ecophysiological and ecosystem consequences. Limnol Oceanogr 42:1105-1118

van Houte-Howes KSS, Turner SK, Pilditch CA (2004) Spatial differences in macroinvertebrate communities in intertidal seagrass habitats and unvegetated sediment in three New Zealand estuaries. Estuaries 6:945-957

van Keulen M, Borowitzka MA (2002) Comparison of water velocity profiles through morphologically dissimilar seagrasses measured with a simple and inexpensive current meter. Bull Mar Sci 71:1257-1267

Viejo RM (1997) The effects of colonization by Sargassum muticum on tidepool macroalgal assemblages. J Mar Biol Assoc UK 77:325-340

Vitousek PM, Mooney JA, Lubchenco JA, Melillo JM (1997) Human domination of Earth's ecosystems. Science 277: 494-499

Wallentinus I (1999) Case histories on introduced species: their general biology, distribution range expansion and impact. Sargassum muticum. Department of Fishery Biology, University of Kiel

Webster PJ, Rowden AA, Attrill MJ (1998) Effects of shoot density on the infaunal macro-invertebrate community within a Zostera marina seagrass bed. Estuar Coast Shelf Sci 47:351-357

Williamson M (1996) Biological invasions. Chapman \& Hall, London

Word JQ (1979) Marine environmental assessment aided by the use of the Infaunal Trophic Index. In: Proceedings of the Ecological Damage Assessment Conference, 12-14 Nov 1979. Arlington, VA, p 41-58

Submitted: July 13, 2005; Accepted: February 7, 2006

Proofs received from author(s): August 16, 2006 